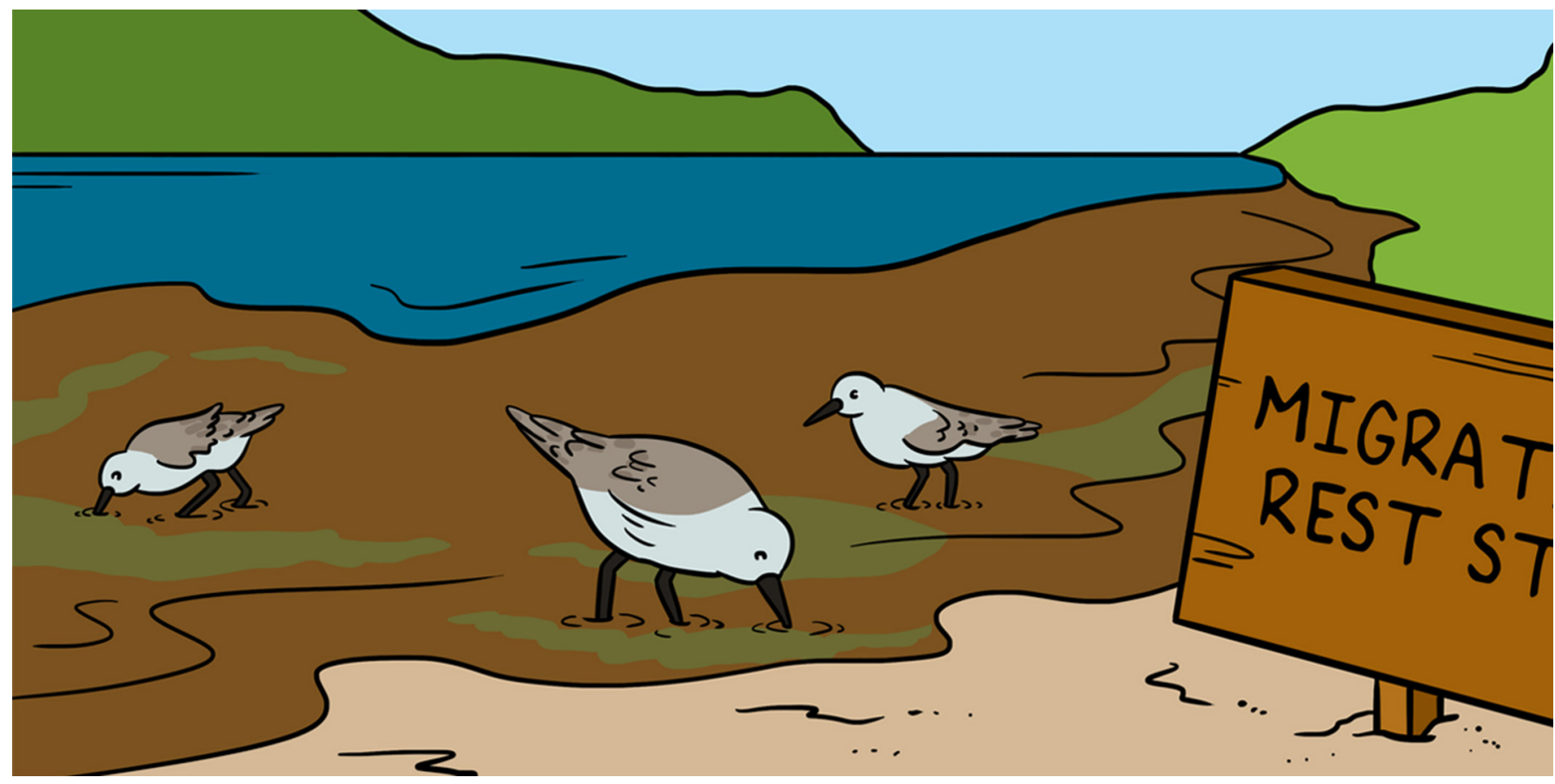

\title{
SMALL SHOREBIRDS FEAST ON GREEN SLIME TO FUEL THEIR LONG MIGRATION
}

Laurie A. Hall ${ }^{1 *}$, Susan E. W. De La Cruz ${ }^{1}$, Isa Woo ${ }^{1}$, Tomohiro Kuwae ${ }^{2}$, David M. Nelson ${ }^{1}$ and John Y. Takekawa ${ }^{3}$

${ }^{1}$ San Francisco Bay Estuary Field Station, Western Ecological Research Center, U.S. Geological Survey, Moffett Field, CA, United States

${ }^{2}$ Coastal and Estuarine Environment Research Group, Port and Airport Research Institute, Yokosuka, Japan

${ }^{3}$ Suisun Resource Conservation District, Suisun City, CA, United States

YOUNG REVIEWER:

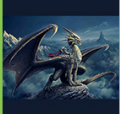

ROWAN

AGE: 9
Shorebirds wade in shallow waters along shorelines searching for food. More than a million shorebirds visit the San Francisco Estuary each year during their migration to feast on the insects, worms, clams, and crabs that live on or under the surface of the sand or mud. The abundant food in the Estuary provides shorebirds with the energy they need to migrate thousands of kilometers, between their breeding areas in the Arctic and their wintering areas along the Pacific coast of North and South America. Scientists have discovered that, during migration, small species of shorebirds eat a green slime called biofilm that grows on the surface of the mud. Larger shorebirds do not eat biofilm. This article describes how the bills and tongues of small shorebirds help them eat biofilm, what biofilm is, and why biofilm is an important food for those birds during migration. 
Figure 1

Outlines of seven different shorebird species, showing differences in their sizes and shapes.

\section{BENTHIC}

INVERTEBRATES

Tiny creatures without backbones, like insects, worms, clams, and crabs, that live on or under the surface of the sand or mud.

\section{PREY}

A creature that is captured and eaten by another creature.

\section{BIOFILM}

A slimy mixture of plant-like creatures, bacteria, and detritus that forms on the surface of the mud and provides food for migrating shorebirds and other creatures.

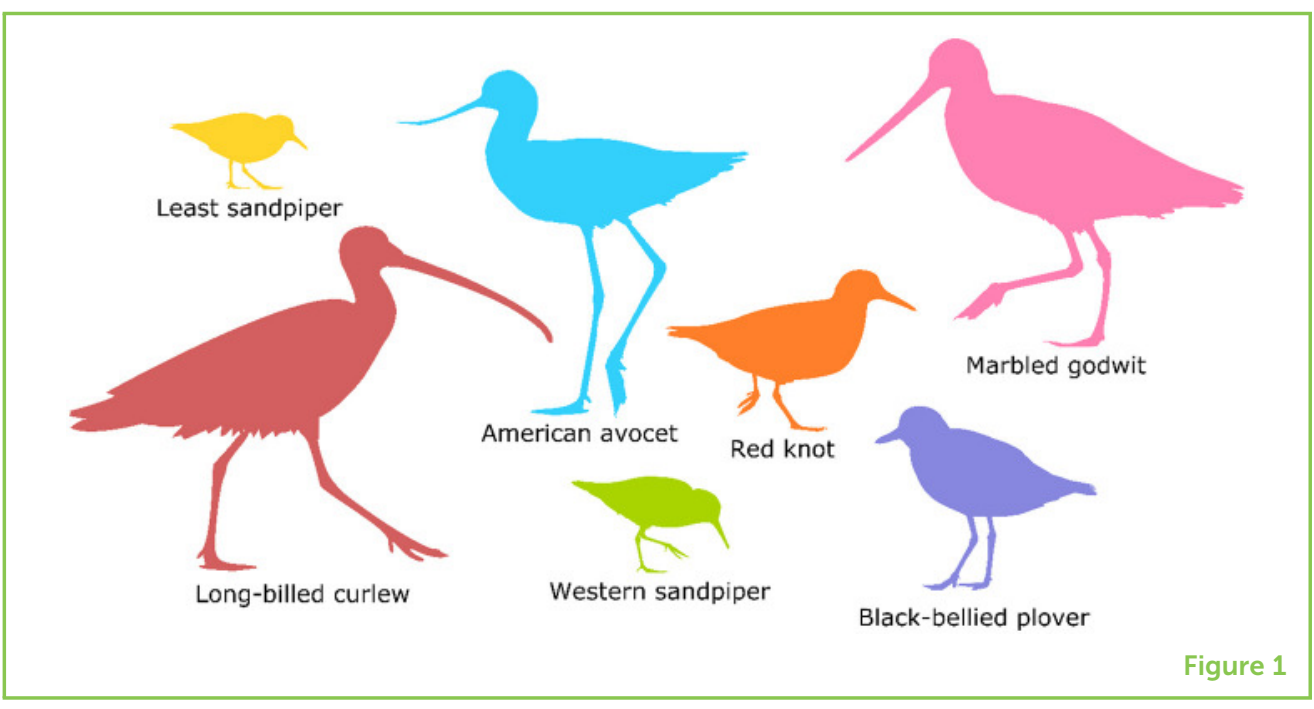

\section{SHOREBIRDS COME IN MANY DIFFERENT SHAPES AND SIZES}

Shorebirds are often found along shorelines, wading in shallow waters in search of food. They eat benthic invertebrates-tiny creatures without backbones, like the insects, worms, clams, and crabs that live on or under the surface of the sand or mud. Shorebirds come in all shapes and sizes, and these differences allow them to eat different types of food so that they can avoid competition with one another (Figure 1). Some, like the marbled godwit, long-billed curlew, and American avocet, have long legs for wading in the water. Others, like the western and least sandpipers, have short legs, so they scurry along the water's edge. The size and shape of a shorebird's bill determine what type of prey it can capture and eat. Shorebirds with longer and more curved bills, like the marbled godwit and long-billed curlew, can probe deep into the mud to capture buried prey like worms and clams. The slightly curved shape makes their bills strong and sturdy for probing. Shorebirds with shorter, straighter bills, like the black-bellied plover, red knot, western sandpiper, and least sandpiper, spend more time pecking at prey that live on the surface of the mud because their bills are too short to probe deep into the mud. In addition to benthic invertebrates, scientists have discovered that some species of shorebirds eat a soupy slime called biofilm that grows on the surface of the mud [1]. However, not all shorebirds eat biofilm. Only the smallest species of shorebirds eat it, and they eat more of it during their spring migration [1, 2]. But why?

\section{SHOREBIRDS NEED A LOT OF ENERGY TO MIGRATE LONG DISTANCES}

Migration is the movement of animals from one place to another during different seasons. Many animals migrate, but shorebirds have some of the longest migration routes of any species. In the fall, as the 
Figure 2

A map of western sandpiper migration between their breeding areas in the Arctic and their wintering areas along the Pacific coast of North and South America. The San Francisco Estuary in California is an important place where more than one million shorebirds stop during their migrations to feast on benthic

invertebrates and biofilm (Basemap credits: National Geographic, Esri, Garmin, HERE, UNEP-WCMC, USGS, NASA, ESA, METI, NRCAN, GEBCO, NOAA, increment $P$ Corp).

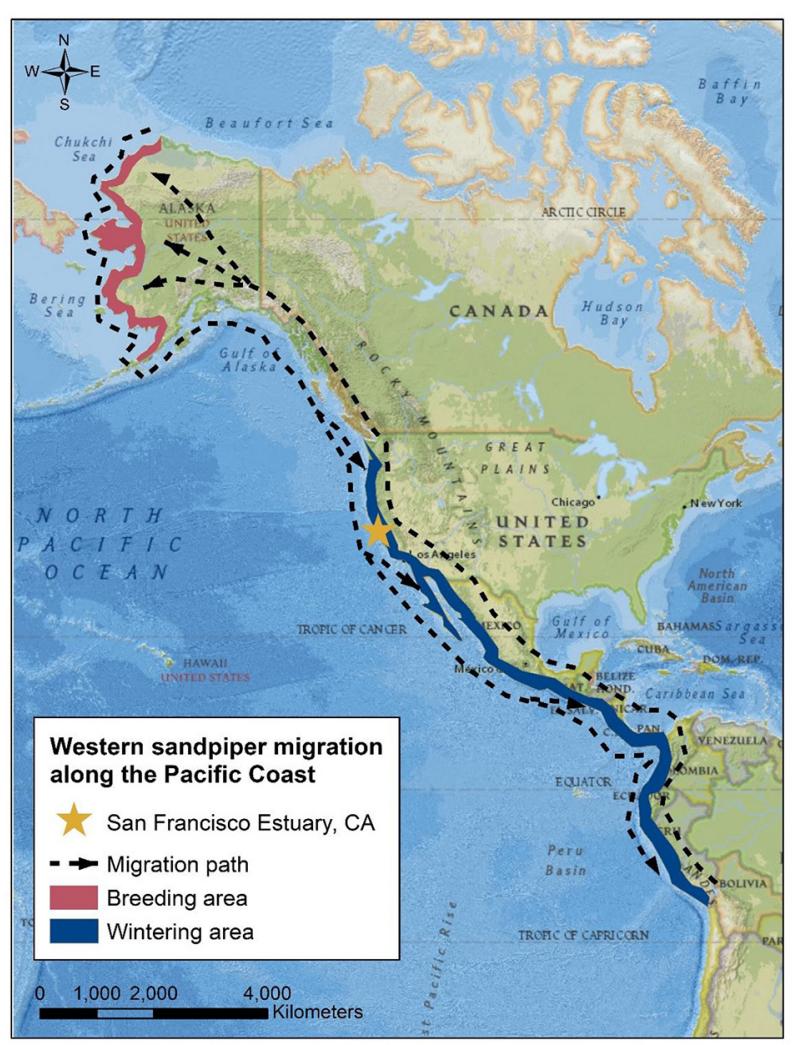

Figure 2

weather gets colder, shorebirds on the west coast of North America migrate thousands of kilometers from their breeding areas in the Arctic to warmer areas along the Pacific coast of North and South America, where they spend the winter. In the spring, they migrate back to their breeding areas. Take the western sandpiper, for example. It is a small species of shorebird that weighs $30 \mathrm{~g}$, a little less than a slice of bread. Some western sandpipers migrate from their breeding areas in northern Alaska all the way to wintering areas in Peru. When the winter is over, they migrate back to Alaska (Figure 2). That is a long way for a little bird to travel, and the migratory flights require a lot of energy.

To prepare for migration, shorebirds need to eat a lot of food to save up extra energy. They gorge themselves every day and store the extra food as fat to use as fuel. As they migrate, shorebirds burn energy and use up their stored fat. They stop along their migratory route at places with abundant food so that they can refuel. These refueling stations are called stopover sites. Often, shorebirds spend only a few days at each stopover site, so they need to quickly eat a lot of food before they continue their migration. The San Francisco Estuary on the coast of central California is one of the most important stopover sites in the Northern Hemisphere (Figure 2). More than one million migratory shorebirds visit the Estuary each year to feast on benthic invertebrates and biofilm [3]. 


\section{DETRITUS}

Small particles of decomposing plants and animals.

\section{PHOTOSYNTHESIS}

Chemical reactions in plants and plant-like creatures that convert carbon dioxide, water, and light energy from the sun into chemical energy that can be used by creatures.

\section{OOZE}

A thick liquid that flows slowly.

\section{WHAT IS BIOFILM?}

Biofilm is a slimy mixture of tiny, plant-like creatures, bacteria, and detritus. It comes in a range of colors from green to golden brown. Biofilm forms near the shoreline, and it can be seen on the surface of the mud as the tide goes out. During low tide, the plant-like creatures move up through the mud to reach the surface where there is sunlight for photosynthesis. They secrete an ooze that helps the biofilm stick together, creating a thin layer of slime on the mud. This slime has a lot of nutrients like fats and sugars, and it is an important food for many animals that live along shorelines, like benthic invertebrates, fishes, and shorebirds. These animals compete for biofilm, and, without it, they might not have enough food. The plant-like creatures that make up biofilm need sunlight for photosynthesis, so there is more biofilm on the mud in the spring and summer when there are more hours of sunlight during the day [4]. In fact, the amount of biofilm on the mud increases in the spring when the shorebirds start their spring migration.

\section{HOW DO SHOREBIRDS EAT BIOFILM?}

Scientists compared the bills and tongues of small species of shorebirds that eat biofilm to the bills and tongues of larger shorebird species that do not eat biofilm. They found that the tongues of small shorebirds have hundreds of tiny bristles, like a broom, that help the birds scrape biofilm off the surface of the mud (Figure 3A) [1, 5]. Large species of shorebirds do not have bristled tongues (Figure 3B) [1]. Small shorebirds also have shorter, straw-like bills that make it easier to slurp up biofilm, while large shorebirds have longer bills [2, 5]. Even though the longer bill of a large shorebird might look like a straw, it is harder to slurp up biofilm with a longer bill. Longer bills are better for probing the mud.

\section{WHY DO SHOREBIRDS EAT BIOFILM?}

Eating biofilm might sound gross, but for a migrating shorebird, biofilm is like an energy drink. Scientists think that small shorebirds might eat biofilm during their migration because it is a quick and easy snack. Why spend lots of time searching for and capturing benthic invertebrates when biofilm is easy to find and easy to eat? Another reason why small shorebirds might eat biofilm is because it is full of nutritious fats and sugars. Biofilm provides shorebirds with nutrients that give the birds fuel to fly long distances [4]. This could explain why shorebirds eat biofilm during migration when they need extra energy for their long flights [2]. It is also possible that small shorebirds eat biofilm during migration to avoid competing for food with larger shorebirds when the birds use the same stopover sites. Millions of shorebirds use 
Figure 3

(A) A small shorebird, the western sandpiper, and a magnified image of the tip of a sandpiper's tongue, showing bristles that help the bird scrape biofilm off the mud. The bristles are very thin. Each bristle is the width of three human hairs. (B) A large shorebird, the long-billed curlew, and a magnified image of the curlew's tongue, showing smooth edges with no bristles.

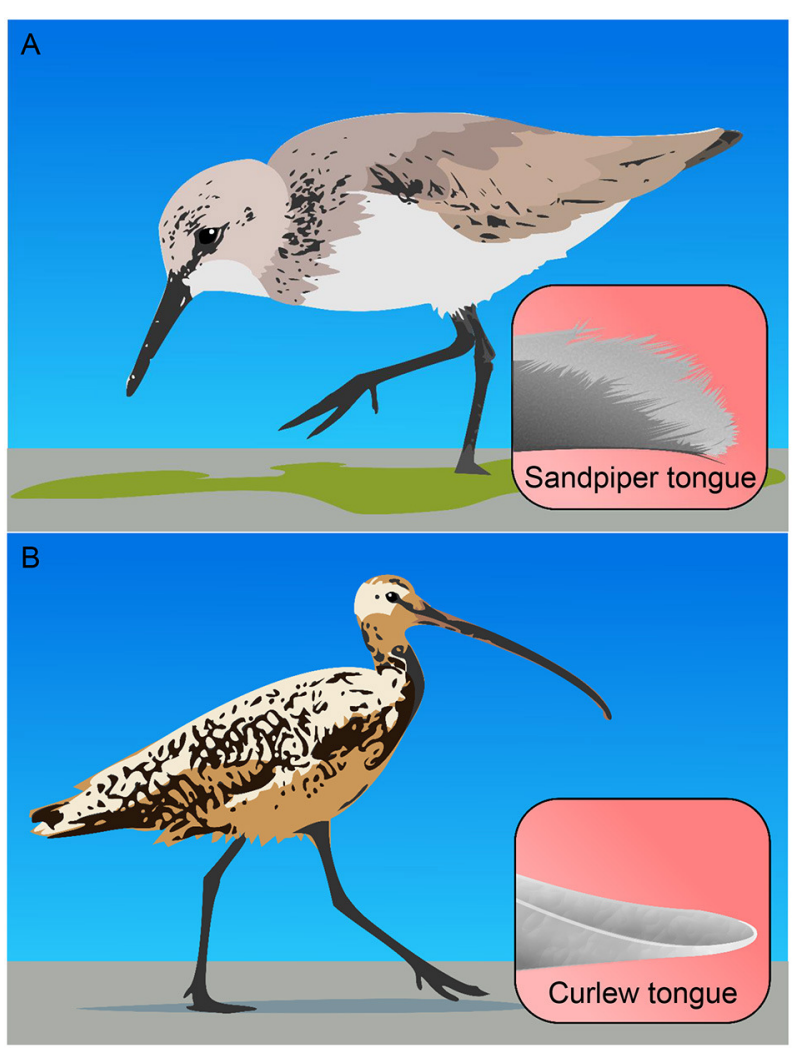

Figure 3

stopover sites along the west coast of North America, including the San Francisco Estuary. Imagine if all the birds at a stopover site ate the same type of food. The food would run out very quickly, and many birds would be left without enough energy to continue their migration. By eating biofilm, small shorebirds can avoid competing with larger shorebirds for benthic invertebrates.

Biofilm sounds like a pretty great food. You might be wondering why large shorebirds do not have the tongues and bills to eat biofilm like small shorebirds. It is because large shorebirds need more energy than small shorebirds. Even though biofilm is a nutritious food, it does not have enough energy for a large shorebird. Here is an example: remember the western sandpiper that weighs $30 \mathrm{~g}$ and can migrate between Alaska and Peru? Scientists estimate that western sandpipers can consume enough biofilm to make up $60 \%$ (more than half) of the energy they need each day during migration [1]. They get the rest of their energy by eating benthic invertebrates. Now, compare that to a larger shorebird, the red knot, that weighs four times as much as a western sandpiper $(120 \mathrm{~g})$. If the red knot were to eat the same amount of biofilm as the western sandpiper, the red knot would only get 20\% (much less than half) of the energy it needs each day from biofilm [1]. To meet their energy needs each day during migration, large shorebirds eat benthic invertebrates, because they provide more energy than biofilm. 


\section{ESTUARIES PROVIDE ABUNDANT FOOD FOR SHOREBIRDS}

Biofilm is a nutritious slime that forms a thin layer on the surface of mud along shorelines. Small shorebirds have short, straw-like bills and bristled tongues that help them eat biofilm off the surface of the mud. Large shorebirds are different: they have longer bills for probing and do not have bristled tongues. These differences allow shorebirds to eat different types of food, so that they can avoid competition with one another. Large shorebirds get their energy by eating benthic invertebrates, but small shorebirds feast on biofilm to give them the energy they need to complete their long migrations. Millions of shorebirds visit stopover sites, like the San Francisco Estuary, during migration to gorge on abundant food. Understanding what shorebirds eat helps scientists develop strategies to manage the food available in estuaries and support thriving shorebird populations.

\section{REFERENCES}

1. Kuwae, T., Miyoshi, E., Hosokawa, S., Ichimi, K., Hosoya, J., Amano, T., et al. 2012. Variable and complex food web structures revealed by exploring missing trophic links between birds and biofilm. Ecol. Lett. 15:347-56.

doi: 10.1111/j.1461-0248.2012.01744.x

2. Hall, L. A., De La Cruz, S. E. W., Woo, I., Kuwae, T., and Takekawa, J. Y. 2021. Ageand sex-related dietary specialization facilitate seasonal resource partitioning in a migratory shorebird. Ecol. Evol. 11:1866-76. doi: 10.1002/ece3.7175

3. Page, G. W., Stenzel, L. E., and Kjelmyr, J. E. 1999. Overview of shorebird abundance and distribution in wetlands of the Pacific coast of the contiguous United States. Condor 101:461-71. doi: 10.2307/1370176

4. Schnurr, P. J., Drever, M. C., Kling, H. J., Elner, R. W., and Arts, M. T. 2019. Seasonal changes in fatty acid composition of estuarine intertidal biofilm: implications for western sandpiper migration. Estuar. Coast. Shelf Sci. 224:94-107. doi: 10.1016/j.ecss.2019.04.047

5. Elner, R. W., Beninger, P. G., Jackson, D. L., and Potter, T. M. 2005. Evidence of a new feeding mode in western sandpiper (Calidris mauri) and dunlin (Calidris alpina) based on bill and tongue morphology and ultrastructure. Mar. Biol. 146:1223-34. doi: 10.1007/s00227-004-1521-5

SUBMITTED: 29 September 2020; ACCEPTED: 28 September 2021; PUBLISHED ONLINE: 02 November 2021.

EDITED BY: Theodore M. Flynn, California Department of Water Resources, United States

CITATION: Hall LA, De La Cruz SEW, Woo I, Kuwae T, Nelson DM and Takekawa JY (2021) Small Shorebirds Feast on Green Slime to Fuel Their Long Migration. Front. Young Minds 9:611826. doi: 10.3389/frym.2021.611826 


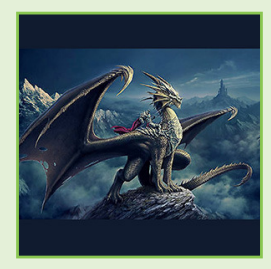

CONFLICT OF INTEREST: The authors declare that the research was conducted in the absence of any commercial or financial relationships that could be construed as a potential conflict of interest.

COPYRIGHT @ 2021 Hall, De La Cruz, Woo, Kuwae, Nelson and Takekawa. This is an open-access article distributed under the terms of the Creative Commons Attribution License (CC BY). The use, distribution or reproduction in other forums is permitted, provided the original author(s) and the copyright owner(s) are credited and that the original publication in this journal is cited, in accordance with accepted academic practice. No use, distribution or reproduction is permitted which does not comply with these terms.

\section{YOUNG REVIEWER}

\section{ROWAN, AGE: 9}

$\mathrm{Hi}$, I am in third grade. I am interested in medieval castles, battles, and historical weapons. I love archery and I have my own bow that is taller than me. I like to play Legos and listen to stories, and I enjoy skateboarding, roller-blading, and scootering. I enjoy camping with my family and whittling with my pocketknife. I invented a world called "Land of the 19 Dragons." I am making the illustrations and I might write a book about it.

\section{AUTHORS}

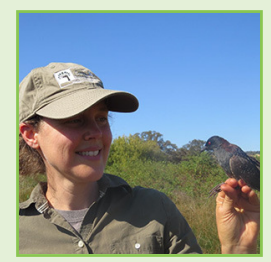

\section{LAURIE A. HALL}

Laurie A. Hall is an ecologist at the U.S. Geological Survey, Western Ecological Research Center. Her research is focused on the movement and foraging ecology of waterbirds. She has been studying waterbirds in California for more than 10 years. She received her doctorate in environmental science, policy, and management from the University of California, Berkeley, her master's degree in marine science from Moss Landing Marine Laboratories, and her bachelor's degree in marine science from Southampton College. When she is not staring at birds through her binoculars, she enjoys hiking and camping with her family and friends. Photo taken before 2020. *lahall@usgs.gov

\section{SUSAN E. W. DE LA CRUZ}

Susan E. W. De La Cruz is a wildlife biologist and senior researcher at the San Francisco Bay Estuary Field Station of the U.S. Geological Survey, Western Ecological Research Center. She is a San Francisco Bay Area native and has studied wildlife in the region for more than 20 years. Her research is focused on foraging and migration ecology, winter habitat use, survival, and contaminant effects in waterbirds. She received her bachelor's degree in biology and her Ph.D. in ecology from the University of California, Davis. She completed her master's degree in wildlife and fisheries sciences at Texas A\&M University. Photo taken before 2020. 


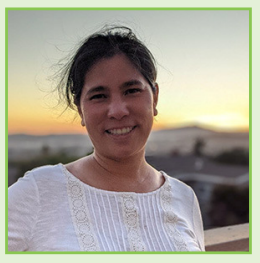

\section{ISA WOO}

Isa Woo is a biologist at the U.S. Geological Survey, Western Ecological Research Center. She has been studying wetland ecosystems and restoration in the San Francisco Bay and Puget Sound regions for over 15 years. Her research is focused on ecosystem functions, such as invertebrate and biofilm prey resources for fish and waterbirds. Isa received her bachelor's degree in integrative biology from the University of California, Berkeley, and her master's degree in botany from the University of Wisconsin, Madison. She enjoys hiking with her husband and two young kids (ages 8 and 5), and gardening to support insect diversity. Photo taken before 2020.

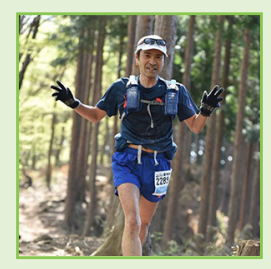

\section{TOMOHIRO KUWAE}

Tomohiro Kuwae is a coastal ecologist and biogeochemist with an interest carbon dynamics and food webs in shallow water ecosystems. He was born in Japan and completed his doctorate there. Tomohiro and his colleagues were the first scientists in the world to discover that western sandpipers eat biofilm as a major part of their diet at a stopover mudflat in British Columbia, Canada. Tomohiro works at the Port and Airport Research Institute in Yokosuka, Japan (https://www.pari.go.jp/unit/ekanky/en/member/kuwae/) where he is currently leading some international blue carbon projects that examine how shallow coastal ecosystems take up atmospheric carbon dioxide. Photo taken before 2020.
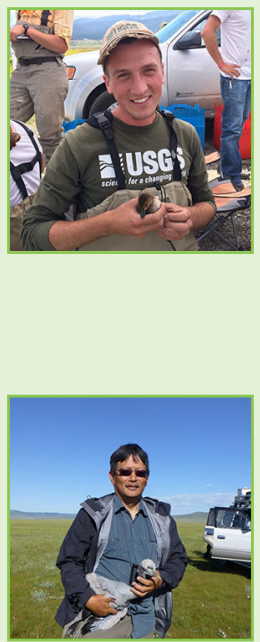

\section{DAVID M. NELSON}

David M. Nelson is a biological science technician at the U.S. Geological Survey's Western Ecological Research Center. He is a Rhode Island native but has worked on waterbird research in the San Francisco Bay Estuary for the past 6 years. He received his bachelor's degree in biological sciences at the University of Rhode Island. When he is not counting birds, he loves to make art and explore. Photo taken before 2020.

\section{JOHN Y. TAKEKAWA}

John Y. Takekawa is the operations manager at the Suisun Resource Conservation District in Suisun Marsh near San Francisco Bay. He is a wildlife biologist who has worked on waterbirds and wetlands in the San Francisco Bay, Pacific Flyway, and Pacific Rim over the past 35 years. He has a doctorate in animal ecology from lowa State University, a master's degree in wildlife biology from the University of Idaho, and a bachelor's degree in forestry from the University of Washington. When he is not chasing birds, he enjoys outdoor activities and watching sports. John is shown holding a Demoseille Crane in Mongolia. Photo taken before 2020. 